Apidologie, 1984, 15 (1), 1-10.

\title{
MICROBIAL FLORA OF THE LARVAL PROVISIONS OF THE SOLITARY BEES, CENTRIS PALLIDA AND ANTHOPHORA SP.
}

\author{
Martha GILLIAM, Stephen L. BUCHMANN and Brenda J. LORENZ \\ U.S. Department of Agriculture, Agricultural Research Service, \\ Carl Hayden Bee Research Center, 2000 E. Allen Road, Tucson, Arizona 85719
}

\begin{abstract}
SUMMARY
All microbes isolated from the larval provisions of two solitary bees, Centris pallida and Anthophora sp. (an undescribed species in the Linsleyi group), were spore-forming bacteria belonging to the genus Bacillus. Bacillus circulans and $B$. coagulans were the most frequent isolates from provisions of $C$. pallida, and $B$. circulans was the only microbe found in the provisions of Anthophora sp. The bacteria isolated produced a variety of enzymes including esterases, proteases, amylases, and glycosidases. These findings are discussed in relation to the presence of Bacillus spp. in the food of other bees that are social. Since Bacillus spp. are well known for their wide range of metabolic activities and their ability to secrete their chemical products, they may be involved in the metabolic conversion, fermentation, and/or preservation of the food of bees.
\end{abstract}

\section{INTRODUCTION}

Recently we examined the larval provisions of the eusocial stingless bee, Trigona hypogea, for microbes which might play a role in the production, metabolic conversion, and/or preservation of stored food (Gilliam et al., 1984). Five species of spore-forming bacteria belonging to the genus Bacillus were the only microorganisms found. Bacillus pumilus was the most frequent isolate followed by $B$. megaterium, B. subtilis, B. circulans, and B. licheniformis. Of interest was the fact that the same species of Bacillus were isolated from pollen of almond, Prunus dulcis, collected and stored in comb cells by honey bees, Apis mellifera, in Arizona (Gilliam, 1979). It appeared that foraging honey bees added many of these bac-

1. Mention of a proprietary product or company names does not constitute an endorsement of this product by the U.S.D.A. 
teria to the pollen as they moistened the grains to make a suitable mass to carry back to the hive since only $B$. subtilis was isolated from fresh pollen collected by hand from the flowers. Since $T$. hypogea uses vertebrate carrion as a protein source in lieu of pollen and since glandular provisions appear to replace stored pollen (RoubIK, 1982), this striking similarity in the microbial complement of different types of food from two social bees may reflect either the ability of $B a-$ cillus spp. to survive in the particular microenvironments or similar metabolic roles of these microbes that have evolved in the nutrition of bees.

To test further these hypotheses, we report here the results of examination of the larval provisions of two additional species of bees, Centris pallida and $A n$ thophora sp. (an undescribed species in the Linsleyi group). In contrast to Apis and T. hypogea, these bees are solitary and nest in soil. Both belong to the family Anthophoridae or «digger bees». They are in the same sub-family but different tribes and are thus phylogenetically related. On the other hand, Apis and Trigona, both in the family Apidae, are closely related. All of these bees, except Apis use mass provisioning of cells ; Apis uses progressive provisioning.

Each female of $C$. pallida constructs a shallow nest which usually contains only one cell (Ascock et al., 1976), or rarely two, and provisions the cell with many loads of pollen. These female bees are quite oligolectic in their choice of pollen for provisioning larval cells and use three species of desert legumes (two species of palo verde and ironwood) primarily. Both males and females are more catholic in the collection of floral nectar which is often gathered from plants other than palo verde or ironwood.

Once the larval cell is about one-third filled with pollen, the female adds a considerable amount of nectar. This is similar to the production of bee bread by honcy bees. However, the larval provisions of $C$. pallida are liquid with the consistency of warm molasses. The female then oviposits floating the egg on the liquid surface, and the cell is then closed.

The Anthophora sp. that we examined had more than one large urn-shaped cell with a wax-like inner lining per nest. Cells of Anthophora characteristically have a thick wax lining. Norden et al. (1980) found that this lining in Anthophora abrupta is composed of liquid triglycerides produced by the Dufour's gland. These authors postulated that the triglycerides were enzymatically converted into solid diglycerides and that they function both as an impervious cell lining and as larval food. Freshly opened cells of large bees of Anthophora species have a «cheesy » or fermented odor which may be due to the waxy lining (NORDEN et al., 1980) or microbial activity (MICHENER, 1974). Anthophora spp. provision cells in a manner similar to $C$. pallida but collect a greater diversity of pollen types (RoBIERTSON, 1928). 
Recently, CANE et al. (1983) showed in laboratory tests that volatile acyclic terpenoid and fatty acid derivatives released from the mandibular glands of female solitary bees during digging inhibited some fungi and bacteria associated with spoilage of provisions and diseases of larvae. Thus, the combination of antimicrobial substances of glandular origin and the lining of the cells protects the provisions from potentially harmful contaminants. Females of $C$. pallida have large Dufour's glands (Ar.cock and BuchmanN, 1984), and they produce a cell lining.

\section{MATERIALS AND METHODS}

Cells of $C$. pallida were collected $4 \mathrm{~km}$ north of Mesa, Arizona in May 1980. They were individually removed intact from the sandy soil and placed upright in sand in paper egg cartons for transport to Tucson in an air-conditioned automobile. Thus, the liquid provisions were prevented from mixing by running over the interior of the cells. Cells were placed in a freezer at the laboratory until they were analyzed.

We attempted to do as many analyses as possible on the larval provisions of the few available cells. Thus, 3 cells each were used to determine the following : weight of the individual cells including the provisions, percent total dissolved solids in the provisions by use of a hand refractometer, microscopic pollen identification, $\mathrm{pH}$, volume of pure nectar in the uppermost layer, and moisture content of the provisions after drying samples at $60^{\circ} \mathrm{C}$ for $3-4$ days and then comparing weight differences. All cells used for analyses, including microbiological determinations, contained viable, apparently healthy eggs.

Cells of Anthophora sp. were removed from earthen nests located approximately $32 \mathrm{~km}$ east of Grand Junction, Colorado on the Colorado River in Garfield County in June 1980. They were hand-carried to Tucson via bus and thus were held at ambient temperature until they reached the laboratory where they were held in a freezer until analyzed. Robert W. Brooks (University of Kansas, Lawrence) has determined that this bee is an undescribed species in the Linsleyi group and will describe it in a future publication.

Because of the small number of Anthophora sp. cells available, only moisture content of the provisions was determined. Cells used for all analyses contained apparently healthy eggs or first or second instar larvae feeding on the provisions.

Since microbiological examination of the provisions was only one aspect of the experiments involving $C$. pallida and Anthophora sp., we were able to plate provision material from one cell of each species. Cell's were opened using aseptic conditions by removing the soil, swabbing the cell with $70 \%$ ethanol, and puncturing the top of the cell with a sterile dissecting needle. A sterile capillary pipet was used to mix the provision material in each cell to avoid sampling only the nectar on the top or the pollen on the bottom.

Larval provisions from each cell were inoculated onto duplicate plates of nutrient agar (Difco), Czapek solution agar (Difco), and YM-1 agar (WICKERHAM, 1951) to isolate bacteria, yeasts, and molds. To test for the presence of anaerobes and microaerophilic organisms, duplicate tubes of thioglycollate medium without indicator (Difco) were inoculated. One plate or tube of each medium was then incubated at $25^{\circ} \mathrm{C}$ and the other at $37^{\circ} \mathrm{C}$ under aerobic conditions. During a 2-week incubation period, plates and tubes were examined periodically for microbial growth, and any colonies that developed were re-streaked onto plates of nutrient agar to test for and prepare pure cultures for identification. These plates were incubated at $37^{\circ} \mathrm{C}$. 
Cell suspensions from all microbial colonies were stained by the Gram method and found to be spore-forming bacterial rods belonging to the genus Bacillus. This was confirmed by microscopic examination of the larval provisions. In this manner, the size, shape, and location of the spores within the sporangia were noted, and the morphology of the vegetative cells was determined. The organisms were maintained on slants of nutrient agar and were tested and identified according to the methods of GoRDON et al. (1973) except that motility was determined in motility test medium (BBL) rather than microscopically.

Additional information on the enzymatic activity of each of the isolates was obtained by testing with the API ZYM system (Analytab Products), for 19 enzymes according to the manufacturer's directions.

\section{RESULTS}

Provisions of $C$. pallida were bright orange due to the abundant palo verde pollen and filled one-third to one-half of the cell. The only pollen present belonged to both species of palo verde exploited by $C$. pallida. The provisions had a layer of moist but firm pollen at the bottom of the cell, a middle portion that was more liquid toward the surface, and a top layer of 100-200 $\mu \mathrm{l}$ of clear nectar with some floating droplets of lipids from the pollen below. The weight of the cells including the provisions ranged from $2.9-4.15 \mathrm{~g}$, and the provision material amounted to $1-2 \mathrm{ml}$ of liquid in each cell. The total dissolved solids ranged from $60-70 \%$, and the $\mathrm{pH}$ of the provisions was 5-6. The moisture content ranged from 15.3-16.3\% water.

Cell provisions of Anthophora sp. had a moisture content that ranged from $10.0-36.8 \%$ with an average of $23.4 \%$. They were light orange in color and were homogeneous throughout with a thin layer of nectar of approximately $25 \mu \mathrm{l}$ on the surface. These provisions had a fairly strong «cheesy » odor resembling that of butyric or isobutyric acid. The provisions of $C$. pallida had a mild «cheesy» odor that was barely detectable.

TABL. 1. - Bacillus spp. isolated from larval provisions of Centris pallida and Anthophora $s p$.

\begin{tabular}{l|c|c}
\hline Source & Organism & No. of isolates \\
\hline Centris palida & Bacillus circulans & 9 \\
& B. coagulans & 8 \\
& B. firmus & 1 \\
Anthophora sp. & B. megaterium & 1 \\
\hline
\end{tabular}

All microbes isolated from the larval provisions of $C$. pallida and Anthophora sp. were bacteria belonging to the genus Bacillus (Table 1). Thirty-five isolates 
belonging to four species were identified. Bacillus circulans and $B$. coagulans were the most frequent isolates from provisions of $C$. pallida, and $B$. circulans was the only microbe found in the provisions of Anthophora sp. One isolate each of $B$. firmus and $B$. megaterium was also found in provisions of $C$. pallida.

Four atypical isolates of $B$. circulans were encountered. Three from provisions of C. pallida did not hydrolyze starch, and one from provisions of Anthophora sp. produced indole and did not hydrolyze starch. According to WILLEMSECollinet et al. (1980), these reactions can occur with a small percent of $B$. circulans isolates, and GoRDon et al. (1973) lists two strains of $B$. circulans as \pm for starch hydrolysis. We prefer to recognize variability within a species rather than assigning new names to strains which differ in only one or two biochemical reactions from described species since in all other respects, our isolates of $B$. circulans conformed to the reactions given by GoRDon et al. (1973).

All isolates of Bacillus spp. from provisions of $C$. pallida produced catalase and fermented $\mathrm{D}(+)$-glucose with acid production only. Of the 19 isolates, 17 fermented $\mathrm{D}(+)$-trehalose, 15 fermented (D-)-mannitol, and 14 fermented $\mathrm{L}(+)$-arabinose and $\mathrm{D}(+)$-xylose with acid production only. Seventeen produced acid in litmus milk, 16 hydrolyzed starch, 16 reduced nitrates to nitrites, 14 decomposed cascin, 14 used citrate as the sole carbon source, 10 grew at $\mathrm{pH} 5.7$, 12 grew in $5 \% \mathrm{NaCl}, 8$ produced acetylmethylcarbinol, 8 produced dihydroxyacetone from glycerol, 3 grew in $7 \% \mathrm{NaCl}$, and 3 liquefied gelatin.

Of the 16 isolates from provisions of Anthophora sp., all produced catalase and fermented $\mathrm{D}(+)$-glucose and $\mathrm{L}(+)$-arabinose with acid production only. Fifteen decomposed casein and hydrolyzed starch; 14 fermented $\mathrm{D}(+)$-xylose, $\mathrm{D}(-)$-mannitol, and $\mathrm{D}(+)$-trehalose with acid production only; 11 decomposed tyrosine ; 10 reduced nitrates to nitrites ; 9 produced acid in litmus milk; 7 used citrate as the sole carbon source ; and 4 grew in $5 \% \mathrm{NaCl}$. None produced acetylmethylcarbinol, grew in $7 \% \mathrm{NaCl}$, or grew at pH 5.7. Only one liquefied gelatin.

The enzymatic activities of the isolates as determined by the API ZYM system are shown in Table 2. One of the B. circulans isolates from provisions of Anthophora sp. died and was not tested. All isolates were negative for $\mathrm{N}$-acetyl$\beta$-glucosaminidase, $\alpha$-mannosidase, and $\alpha$-fucosidase, and all produced phosphoamidase.

Myristate lipase, cystine aminopeptidase, and $\beta$-glucuronidase were not produced by isolates from provisions of $C$. pallida. Most of the isolates from this source produced butyrate esterase, leucine aminopeptidase, caprylate esteraselipase, and alkaline phosphatase. Most of the isolates from provisions of Anthophora sp. produced leucine aminopeptidase, chymotrypsin, and caprylate esteraselipase. 
TABL. 2. - Results of tests for enzymes produced by Bacillus spp. isolated from larval provisions of Centris pallida and Anthophora $s p$.

\begin{tabular}{l|c|c}
\hline \multicolumn{1}{c}{ Enzyme } & \multicolumn{2}{|c}{ No. positive/no. tested from } \\
\cline { 2 - 3 } & C. pallida & Anthophora sp. \\
\hline Alkaline phosphatase & $16 / 19$ & $5 / 15$ \\
Butyrate esterase & $18 / 19$ & $7 / 15$ \\
Caprylate esterase-lipase & $17 / 19$ & $12 / 15$ \\
Myristate lipase & $0 / 19$ & $2 / 15$ \\
Leucine aminopeptidase & $18 / 19$ & $14 / 15$ \\
Valine aminopeptidase & $5 / 19$ & $6 / 15$ \\
Cystine aminopeptidase & $0 / 19$ & $3 / 15$ \\
Trypsin & $8 / 19$ & $3 / 15$ \\
Chymotrypsin & $6 / 19$ & $14 / 15$ \\
Acid phosphatase & $13 / 19$ & $10 / 15$ \\
Phosphoamidase & $19 / 19$ & $15 / 15$ \\
$\alpha$-Galactosidase & $3 / 19$ & $1 / 15$ \\
$\beta$-Galactosidase & $4 / 19$ & $7 / 15$ \\
$\beta$-Glucuronidase & $0 / 19$ & $1 / 15$ \\
$\alpha$-Glucosidase & $9 / 19$ & $9 / 15$ \\
$\beta$-Glucosidase & $2 / 19$ & $3 / 15$ \\
N-Acetyl- $\beta$-glucosaminidase & $0 / 19$ & $0 / 15$ \\
$\alpha$-Mannosidase & $0 / 19$ & $0 / 15$ \\
$\alpha$-Fucosidase & $0 / 19$ & $0 / 15$ \\
\hline \hline
\end{tabular}

\section{DISCUSSION}

In the present study, the most frequent isolate was $B$. circulans. This bacterium has also been isolated from guts of worker honey bees, $A$. mellifera (GILliam and Morton, 1978; Gilliam and Valentine, 1976); from pollen from the corbiculae of foraging honey bees (GILliam, 1979); and from larval provisions of $T$. hypogea (Gilliam et al., 1984). Bacillus coagulans was a frequent isolate from provisions of $C$. pallida and has been found previously in the guts of both worker honey bees (El-Leithy and El-Sibaei, 1972; Gilliam and Morton, 1978; Gilliam and Valentine, 1976) and mated queens (Gilliam, 1978). $B$. megaterium has been isolated from guts of worker honey bees (EL-LEITHY and El-Sibaer, 1972; Gilliam and Morton, 1978), pollen from the corbiculae of foraging honey bees (Gilliam, 1979), guts of virgin and mated queen honey bees 
(Gilliam, 1978), and now from larval provisions of $T$. hypogea (Gilliam et al., 1984). Bacillus firmus has been found in guts of worker honey bees (Gillian and Morton, 1978 ; Gilliam and Valentine, 1976).

Since Bacillus spp. were the only microorganisms found in the provisions of both $C$. pallida and Anthophora sp., they may play a role in the production, metabolic conversion, and/or preservation of the larval provisions of these bees. $B a$ cillus spp. were also the only microbes found in the provisions of $T$. hypogea, bees which appear to digest dead animal tissue to obtain nutrient compounds that are then transported to the hypopharyngeal glands which produce the larval cell provisions (ROUBiK and BUCHMANN, unpublished).

MaCHado (1971) reported that a bacterium similar to B. pumilus appeared to predigest pollen collected by Melipona quadrifasciata. Elimination of the bacterium caused destruction of comb cells by the workers and the eventual death of the colony. The Bacillus appeared in large numbers only in the glandular secretion deposited on the pollen and honey layers in the cells. Furthermore, Bacillus, apparently of more than one species, was found in the larval food of 13 other species of bees in the sub-family Meliponinae (MACHado, 1971).

Also, since Bacillus spp. were isolated from pollen and bee bread collected and stored by honey bees (Gilliam, 1979), it seems possible that a special association between Bacillus spp. and bees has evolved. Female bees may inoculate food sources with microbes that are responsible for the metabolic conversion, fermentation, and preservation of food. The research cited certainly demonstrates the ability of these microbes to survive in the specialized environments and may indicate the resistance of Bacillus spp. to antimicrobial compounds such as those found in glandular secretions and nectar.

Bacillus spp. are well known for their wide range of metabolic activities and their ability to secrete chemical products. These abilities are exploited commercially. They produce many compounds including antibiotics (KATZ and DEMAIN, 1977), fatty acids (KANEDA, 1971) and numerous enzymes (BAPTIST et al., 1978) such as pectinases, cellulases, amylases, proteases, $\beta$-glucanases, and isomerases. These bacteria secrete a number of extracellular enzymes in large quantities and usually produce several enzymes at the same time.

Results of the API ZYM tests revealed that the isolates from larval provisions of $C$. pallida and Anthophora sp. possessed a high activity of enzymes involved in lipid and protein metabolism and lower activity of glycosidases that hydrolyze carbohydrates. This was true also of the Bacillus spp. isolated from provisions of $T$. hypogea (Gilliam et al., 1984). Approximately half of the isolates in the present study produced $\alpha$-glucosidase that hydrolyzes compounds such as sucrose, trehalose, melezitose, raffinose, and maltose. This is in contrast to the 
production of this enzyme by only 2 of 15 isolates from provisions of $T$. hypogea (Gilliam et al., 1984) and probably reflects the higher concentration of these carbohydrates in provisions of $C$. pallida and Anthophora sp. However, isolates from $T$. hypogea had a higher activity of $\beta$-glucosidase that hydrolyzes carbohydrates such as cellibiose and salicin.

A higher proportion of the isolates from $C$. pallida compared to those from Anthophora sp. produced alkaline phosphatase, butyrate esterase, and trypsin. On the other hand, a greater percent of the isolates from Anthophora sp. produced chymotrypsin and $\beta$-galactosidase. Differing patterns of enzymatic activity by microbes from two sources may reflect adaptation to the chemical composition of specific food resources. Similar high activities were found for caprylate esteraselipase, leucine aminoppetidase, acid phosphatase, and phosphoamidase by isolates from both sources as well as from T. hypogea (Gilliam et al., 1984).

Therefore, the results of both the API ZYM tests and the taxonomic tests showed that a wide variety of enzymes capable of acting on a variety of substrates was produced by the Bacillus spp. isolated. These enzymes include esterases, proteases, amylases, and glycosidases.

The production of both antibiotics and fatty acids by Bacillus spp. in larval provisions could limit the types of microbes that are able to survive, inhibit competition by other microbes for this food source, and protect the food from spoilage. The low $\mathrm{pH}$ of provisions may aid in this regard as well. Thus, these bacteria may be necessary for the maintenance of proper nutrition.

As previously stated, we are aware of the limitations of the small sample size used in this study but realized that we would be unable to obtain additional material from these species. In the future, we hope to examine provisions of additional species of bees to determine whether the association of Bacillus spp. with food sources is widespread among these insects.

Received for publication in December 1983. Accepted for publication in February 1984.

\section{ACKNOWLEDGMENT}

We thank Mr. Robert J. Schmalzel for collecting the cells of Anthophora sp. Two pinned bees as vouchers and all earthen cell materials have been deposited in the Snow Entomological Museum at the University of Kansas, Lawrence and are under the care of Mr. Robert W. Brooks. 


\section{RÉSUMÉ}

\section{LA FLORE MICROBIENNE DES PROVISIONS LARVAIRES DES ABEILLES SOLITAIRES CENTRIS PALLIDA ET ANTHOPHORA. SP.}

On a recherché la présence de bactéries, de levures et de moisissures dans les provisions larvaires de deux abeilles solitaires, Centris pallida et Anthophora sp. (espèce non décrite du groupe Linsleyi), en les étalant sur un milieu microbiologique approprié, et aussi en examinant directement au microscope le matériau des provisions. Tous les microbes trouvés sont des bactéries qui forment des spores et appartiennent au genre Bacillus. Bacillus circulans et $B$. coagulans sont les espèces les plus fréquemment isolées des provisions de $C$. pallida; $B$. circulans est le seul microbe trouvé dans les provisions d'Anthophora sp.

Les résultats de 19 tests enzymatiques utilisant le système API ZYM montrent que les espèces de Bacillus isolées possèdent une activité enzymatique élevée impliquée dans le métabolisme des lipides et des protéines et une activité plus faible des glycosidases, qui hydrolysent les hydrates de carbone. Une proportion plus grande de bacilles provenant de $C$. pallida, par rapport à ceux provenant d'Anthophora sp., produit de la phosphatase alcaline, de la butyrate esterase et de la trypsine. Pourtant un pourcentage plus élevé de bacilles venant d'Anthophora sp. produit de la chymotrypsine et de la $\beta$-galactosidase. Les bacilles des deux origines montrent une activité semblablement élevée pour la caprylate esterase-lipase, la leucine aminopeptidase, la phosphatase acide et la phosphoamidase.

Ces résultats sont discutés en rapport avec le large spectre d'activités métaboliques de Bacillus spp. d'une part et, d'autre part avec la présence de Bacillus spp. dans la nourriture d'autres abeilles, qui sont sociales. Il se peut qu'une association particulière se soit développée entre les abeilles et Bacillus spp. et ces microbes ont pu jouer un rôle dans la conversion métabolique, la fermentation et/ou la conservation des sources alimentaires.

\section{ZUSAMMENFASSUNG}

\section{DIE MIKROBENFLORA DES LARVENFUTTERS DER SOLITAREN BIENEN CENTRIS PALLIDA UND ANTHOPHORA SP.}

Das Larvenfutter von zwei solitären Bienen, Centris pallida und Anthophora sp. (eine unbeschriebene Art aus der Linsleye Gruppe) wurde auf Bakterien, Hefen und Schimmelpilze untersucht, und zwar durch Ausstriche auf geeignete Nährböden und durch direkte mikroskopische Untersuchung des zur Fütterung eingelagerten Materials. Alle aufgefundenen Mikroben waren sporenbildende Bakterien aus dem Genus Bacillus. Bacillus circulans und B. coagulans waren die häufigsten Isolate aus den Futtervorräten von $C$. pallida. B. circulans war die einzige Mikrobe, die in dem Futter von Anthophora gefunden wurde.

Die Versuche mit API-ZYM-System Tests, die 19 Enzyme erfassen, ergaben bei den Isolaten von Bacillus spp. eine hohe Enzymaktivität im Lipid- und Protein-Metabolismus und eine geringere Aktivität đer Glukoxidase, die Kohlehydrate hydrolysiert. Ein größerer Prozentsatz der Isolate von C. pallida als von Anthophora sp. produzierte basische Phosphatase, Butyrat-Esterase und Trypsin. Dagegen erzeugte ein größerer Anteil von Anthophora-Isolaten Chymotrypsin und $\beta$-Galactosidase. Bei Isolaten von beiden Arten wurden ähnlich hohe Aktivitäten für Caprylat-Esterase-Lipase, LeucinAminopeptidase, saure Phosphatase und Phospho-Amidase festgestellt.

Diese Ergebnisse wurden in Bezug auf das breite Wirkungsspektrum der Stoffwechselaktivität von Bacillus spp. und in Hinblick auf das Vorhandensein von Bacillus spp. im Futter von Bienen mit sozialer Lebensweise diskutiert. Es könnte sich eine spezifische Beziehung zwischen Bienen und Bacillus-Arten entwickelt haben, und diese Mikroben könnten in der metabolischen Umwandlung, der Fermentierung und/oder der Konservierung der Nahrung eine Rolle spielen. 


\section{REFERENCES}

Alcock J., BuchmanN S.L., 1984. - The significance of post-insemination display by male Centris pallida (Hymenoptera : Anthophoridae). Z. Tierphysiol., in press.

Alcock J., Jones C.E., Buchmann S.L., 1976. - The nesting behavior of three species of Centris bees (Hymenoptera : Anthophoridae). J. Kansas entomol. Soc., 49, 469-474.

Baptist J.N., Mandel M., Gherna R.L., 1978. - Comparative zone electrophoresis of enzymes in the genus Bacillus Int. J. Syst. Bacteriol., 28, 229-244.

Cane J.H., Gerdin S., Wife G., 1983. - Mandibular gland secretions of solitary bees (Hymenoptera : Apoidea) : potential for nest cell disinfection. J. Kansas entomol. Soc., 56, 199-204.

El-Leithy M.A., El-Sibaei K.B., 1972. - External and internal microflora of the honey-bees (Apis mellifera L.). Egypt. J. Microbiol., 7, 79-87.

Gilliam M., 1978. - Bacteria belonging to the genus Bacillus isolated from selected organs of queen honey bees, Apis mellifera. J. Invertebr. Pathol., 31, 389-391.

Gilliam M., 1979. - Microbiology of pollen and bee bread : the genus Bacillus. Apidologie, 10, 269-274.

Gilliam M., MORTON H.L., 1978. - Bacteria belonging to the genus Bacillus isolated from honey bees Apis mellifera, fed 2,4-D and antibiotics. Apidologie, 9, 213-221.

Gilliam M., Valentine D.K., 1976. - Bacteria isolated from the intestinal contents of foraging worker honey bees, Apis mellifera : the genus Bacillus. J. Invertebr. Pathol., 28, 275-276.

Gilliam M., Buchmann S.L., Lorenz B.J., Roubik D.W., 1984. - Microbiology of the larval provisions of the stingless bee, Trigona hypogea, an obligate necrophage. Biotropica, in press.

Gordon R.E., Haynes W.C, and Hor-Nay Pang C., 1973 - The genus Bacillus. USDA Handbook, 427.

KANEDA T., 1977. - Fatty acids of the genus Bacillus : an example of branched-chain preference. Bacteriol. Rev., 41, 391-418.

Katz E., Demain A.I., 1977. — The peptide antibiotics of Bacillus : chemistry, biogenesis, and possible functions. Bacteriol. Rev, 41, 449-474.

Machado J.O., 1971. - Simbiose entre as abelhas sociais brasileiras (Meliponinae, Apidae) e uma especie de bacteria. Ciencia e Cultura (Sao Paulo), 23, 625-633.

Michener C.D., 1974. - «The Social Behavior of the Bees». Belknap Press of Harvard University Press, Cambridge, Mass.

Norden B., Batra S.W.T., Fales H.M., Hefetz A., Shaw G.J., 1980. - Anthophora bees : unusual triglycerides from maternal Dufour's glands serve as larval food and cell lining. Science, 207, 1095-1097.

Robertson C.R., 1928. - Anthemoessa abrupta. Psyche, 35, 56-60.

RouBIK D.W., 1982. - Obligate necrophagy in a social bee. Science, 217, 1059-1060.

WICKerham L.J., 1951. - Taxonomy of yeasts. USDA Tech. Bull., 1029.

Willemse-Collinet M.F., Tromp Th.F.J., Huizinga T., 1980. - A simple and rapid computerassisted technique for the identification of some selected Bacillus species using biochemical tests. J. appl. Bacteriol., 49, 385-393. 